\title{
Documentation Of Succulents From Agriculture Farm Of Dehgam Area, Gujarat
}

\author{
Mrunali Kolhe ${ }^{1}$, Shirin Qureshi ${ }^{2}$, Archana Mankad ${ }^{3}$, Hitesh Solanki ${ }^{4}$ \\ ${ }^{1}$ M.Sc. student, ${ }^{2}$ Research Scholar, ${ }^{3,4}$ Professor \\ ${ }^{1,2,3,4}$ Department of Botany, Bioinformatics, Climate Change Impacts Management, Gujarat University, \\ Ahmedabad-9. \\ Emailid: husolanki@yahoo.com
}

\begin{abstract}
Succulents are plants that consume some portions that are more than generally condensed and fleshy, usuallyretain water in arid climates or soil. The word "Succulent" comes from the Latin word 'Sucus' meaning juice or sap. Most of Succulents are native to dry, arid regions such as a desert.Succulents are very interesting group of plants that are found in its natural environment. Mostly in South Africa,succulents are also called xerophytes but not all are xerophytes. The Succulent leaf is highly specialized when the stem is inattentive, leaves grown are hidden in the soil for reducing water loss. Stem succulents belongto cactus family. Succulents stem have leaves which are reduced in size. Root Succulents are associated with annual stems that desiccate duringdry season. We visited Poonam agriculture farm, Ahmedabad, Gujarat in India in year 2018-2019 for 3 months. We saw 296 species of succulents in the field and out of them, we studied 13 genera having above characters which are: Agave, Aloe, Alludia, Crassula, Caralluma, Dyckia, Didierea, Euphorbia, Gasteria, Haworthia, Kalanchoe, Sansevieria, Senecio.From the above study, we conclude that this farm is one of the diverse regions for succulents and cacti found in Gujarat.
\end{abstract}

Keywords: Succulent, Xerophytes, Dry, Gujarat.

\section{INTRODUCTION}

"Succulents are plants that consume some portions that are more than generally condensed and fleshy, usually to retain water in arid climates or soil". The word "Succulent" comes from the Latin word Sucus, meaning juice or sap. Most of succulents are native to dry, arid regionssuch as a desert.

Succulents are very interesting group of plants that are found in its natural environment, mostly in South Africa. Succulents are also called xerophytes but not all are xerophytes. The Succulent leaves are highly specialized when the stem is inattentive leaves grown hidden in the soil for reducing water loss. Stem succulents belong to cactus family. Succulent stem has leaves which are reduced in size. Root Succulent is associated with annual stems that desiccate during the dry season (Anderson, 2006)

2. THE SUCCULENTSCLASSIFIED ARE DIVIDED INTO FOUR MAIN PARTS OF PLANT.

1) Leaf Succulents: Leaf succulent plants are that store water inside their leaves so that they become fleshy.

2) Stem Succulents: Stem Succulents plants have thick fleshy stem that store water in their tissue. The reduction of leaves is not a prerequisite for stem succulents as many stem. Succulents maintain large leaves during the growing season.

3) Caudiciformis:Caudiciformis are plants that evolve water storage organ which is either underground or overground. This organ allows the plant to survive for long time. This organ contains water and nutrients.

4) Bulbous: Bulbous is a storage organ. It is globular with fleshy leaves that store food \&water. It is globular in shape. It is difficult to grow during summer because vines dry up completely, plant gets spots during spring (Dortort,2011).

\section{HABITAT OF SUCCULENTS:}

The habitat of Succulents are diverse, overall the five contains that have concentrations between 30 ' $\mathrm{N}$ and 30'S latitudes among all the largest inSouth Africa and Sub-Tropical America. South Africa is said as the natural home for the widest range of other Succulents. Human interventions have made it difficult to decide the exact native habitat of a species, even less genus (Bewli,2016).

\section{DISTRIBUTION:}

South Africa and subtropical North and South America would score highest for numbers of speciesas well as for density populations. America is the home of the cactaceae family and the Century plants (Agave), Various Crassulaceae (Echeverioideae), somePortulacaceae. Euphorbiaceae and others. South Africa is the home of the widest range of all Succulents. Crassulaceae is distributed in Tillaea (Anderson,2006).

\section{PROPAGATION:}

The main two techniques are Succulents for propagation. 


\section{1) Seed Propagation:}

Not only for succulents but for other plants, one cannot get a real pleasure in growing plants or succulents without the use of seeds.

\section{2) Vegetative Propagation.}

Almost all the succulents lend themselves vegetative multiplication by division, offsets, suckers, cuttings \& grafting.

\subsection{Cutting:}

Some of the matured twigs are to be separated by horizontal cut and dried, for the less of moisture to some extent, sometimes a root promoter is used for advantage. The time of preparing cutting depends on the type of plant.

\subsection{Cutting Propagation:}

While seed propagation is relatively easy, most gardeners have better success with growing from cuttings.

\subsection{Leaf Cutting:}

Propagation by leaf cutting is also useful method practically for Succulents other than cacti. Some of the Succulents are propagated from leaf cuttings are Kalanchoe, Sedum, Gasteria.

\subsection{Grafting:}

It is another method of propagation that involves the union of plant part to be multiplied that is termed as scion with another rooted part called stock (Dortrot,2011).

\section{CULTIVATION OF SUCCULENTS:}

Location:The combination of water, soil, and light should be according to the specific area where the plant is grown. The basic cultural recommendation given from the environment of Ahmedabad, Gujarat in India, is that it is an area of high temperature infrequent moderate winter and summer days with temperature above $42^{\circ} \mathrm{C}-45^{\circ} \mathrm{C}$.

Water: Watering succulent plants is one of the riskiest parts of growing them. Succulents are geniuses of nature that store extra water in their leaves, stem, or root. Because they have the reputation for growing in arid situations, many people fail to understand that when we transport them into our home and garden atmospheres, they do need to be watered regularly.

Climate:Succulents need full sun position and they grow in temperature like hot climate, others are very sensitive to cold in cool season.For the Succulents, winter is a dormant season and summer is growing season.

Temperature: Temperature is an important component for the succulents. Succulents need colder temperatures at night below $30^{\circ} \mathrm{C}$ and in the day, they need full sunny position, temperature between $40^{\circ} \mathrm{C}$ to $45^{\circ} \mathrm{C}$. Difference between night and day temperature is most important for the plant growth especially when Succulents grow in greenhouse.

Soil: Soil is important component for the Succulent growth. Succulent need well drained dry soil. Soil is very important because they provide nutrients. Soil made by mixture of sand, soil, fertilizer \& peat. Soil $\mathrm{pH}$ is to be maintained. Succulent growth is well seen in slightly acidic soil.

Planting: Planting can occurin almost any pot,if allowed enough room to cater for the roots of the plants and sufficient repotting is only ever required when the roots start to burst out from the base of the pot or become obvious on the surface of the soil (Dortort,2011).

Experimental site: $\mathrm{We}$ worked on Succulents in 2018-2019 for 3 months. We visited Poonam Agriculture Farm, Ahmedabad, Gujarat in India. The total area of the farm is 15 acres. The farm environment was dry.There were three greenhouses present in the farm. In the first greenhouse, the covered area was 20 to 30 square meter and other two greenhouses were covered with small area in the farm. Small two greenhouses in the farm were totally covered with the white $50 \%$ shaded film that is the UV stabilizedpolythene film. Mostly Succulents- all the species were in small two greenhouses. In these greenhouses, there are different beds for plantation of Succulents.

\section{DOCUMENTATION OF SUCCULENTS}

In the greenhouse mostly around 296 species of Succulents were observed. Cactiiwere also present in the greenhouses but as compared to cactus,Succulents were less. Out of 296,we studied 13 genera of succulents. The documentation of Succulents was done by describing the following characteristics in detail as: Habitat, Plant body, Flowers, and Propagation.

Agave (Linnaeus): Agave is native to Mexico in North America. It has approximately 200 species in the family Asparagaceae. It is a rosette form ofsucculent. Leaves are leathery and 2.5 meter in length, depend on the species. Mostly, species have their own terminal spine. The flowers are clusters are borne at the top of a very robust flowering stem.

Aloe (Linnaeus): The Aloe grows wild in tropical and sub-tropical lands. They need dry atmosphere. The Succulent leaf of the Aloe is an adaptation to the dry condition. The plant is stem-less or very short-stemmed with an average about 20 leaves in a straight, dense rosette. The leaves can grow up to $40-50 \mathrm{~cm}$ long and $6-7 \mathrm{~cm}$ wide. The plants will bloomafter at least 4 years of age.

Alludia: This genus forms part of the thorn-shrub forest in Madagascar. Most species of Alludia have a juvenile growth form of a branched shrub a few meters, eventually forming a single-trunked tree, branching well above the ground. They will not tolerate prolonged frost but make excellent full-sun 
International Journal of Research in Advent Technology, Vol.7, No.4, April 2019

E-ISSN: 2321-9637

Available online at www.ijrat.org

patio plants, until they grow too large to be moved indoors. Most are easily propagated from cuttings; they are not often grown from seed as it is rarely available (Anderson, 2006; Dortort,2011).

Crassula(Linnaeus): This genus has 200 species of succulent plant with varying ssize. Crassulas are distributed throughout the world but the majority are from South Africa. It is hardy plant. They are small perennial plant and up to $60 \mathrm{~mm}$ height. Flower is cup-shaped, and the petals are 2 and 2.5 mm long (Anderson,2006; Dortort,2011).

Caralluma (Robert Brown): They are native to India. The Caralluma genus is such genus of edible Cacti, that includes some species, grows across India. The stem is up to $15 \mathrm{~cm}$ in height. It is straight branched herb. It has been eaten asvegetable in rural India. Flowers are five-pointed thick stars coloured black, purple or red produced in late summer or autumn (Anderson,2006; Dortort,2011).

Dyckia: Dyckia is very attractive plant up to $20 \mathrm{~cm}$ tall, with rosettes up to $30 \mathrm{~cm}$ wide. The leaves are short, glossy, deep green and purple in full sun and are covered in silvery scales. Most Dyckia species have leaves armed with sharp spikes. In spring to summer, they can appear attractive up to $90 \mathrm{~cm}$ tall stalks of yellow-orange flowers (Anderson,2006; Dortort,2011).

Didierea: The member of the Didiereaceae, found almost nowhere but in Madagascar, may be the most distinctive of that islands succulents. The eponymous genus Didierea consists of two species D. madagascariensis and D. trollii. Seedling of Didierea madagascariensis resemble miniature unbranched mature plants and grow upright, straight as a ruler (Anderson,2006; Dortort,2011).

Euphorbia: Euphorbia genus of Euphorbiaceae family. Itcontains minimum 2100 species and is one of the most diverse groups of flowering plants. The origin of Euphorbia is in Southern and Eastern Africa and Madagascar but they also found in Tropical Asia and America. The leaves are simple, opposite and sessile. The stem is fleshy, terete, branched, reddish and laticiferous (Anderson,2006; Dortort,2011).

Gasteria: Gasterias are thick, hard succulent "tongue-shaped" leaves. It is long leaved, drooping, succulent shrub with long, fleshy stems. Plants are branched from the base with stems becoming overhanging and up to $1 \mathrm{~m}$ long (Anderson,2006 ; Dortort,2011).

Haworthia:The largest genus of dwarf succulents' plant within the family Xanthorrhoeaceae. Origin of Haworthias from South Africa and South West Africa. The genus Haworthia comes from the botanist Adrian Haredy Haworth. The flowers are white and small with single spike (Anderson,2006; Dortort,2011).

Kalanchoe: It is native to Africa, Madagascar and Malaysia. It is a very well-known genus. It is found from the central to the Southern ridge and hills of the Drakensberg. Kalanchoe are grown up to 12 ' inch in height they prefer full sunlight for the growth (Anderson,2006; Dortort,2011).

Sansevieria: It is perennial, rhizomatous herb without stem. Leaves 13-30 in a rosette blade Hardly linear, erect to slightly spreading, margin red with colourless outer point. Native to Africa and Asia (Anderson,2006; Dortort,2011).

Senecio: This genus has thousands of small, annual and perennial shrubs. It has thick leaves thick stem and tuberous. It is native to Africa, Madagascar, Mexico as well as the Canary Island and the East Indies. The plant body looks like green pencil rising from the ground and the main stem has few branches. Flowers are five petals and 2 to $4 \mathrm{~mm}$ long (Anderson,2006; Dortort,2011).

\section{CONCLUSION:}

There are total species of 11,000 to 11,045 approximately and 550 genera of succulents in the world. Out of these we saw 296 species of Succulents in the fieldand studied these 13 genera: Agave, Aloe, Alludia, Crassula, Caralluma, Didierea, Euphorbia, Gasteria, Haworthia, Kalanchoe, Sansevieria, Senecio. Out of these, 3 rare species were observed: Didierea madagascariensis, Alludia procera \& Haworthia cooperi var. truncata. From the above study, we conclude that this farm is one of the diverse regions for Cacti and Succulents found in Gujarat. Due to industrialization, there is a loss of succulents; hence, it is very important to conserve them.

\section{ACKNOWLEDGMENTS}

We would like to thankDr. Vashram P. Boda for providing us guidance and research field. We would also like to thank Department of Botany for providing us the facilities for research work.

\section{REFERENCES:}

[1] Anderson R."The Complete Guide to growing Cacti \& Succulents: A comprehensive guide to identification, care and cultivation". sAnness publishing Ltd, pages 8-17.2006.

[2] Bewli C. S."Cacti Culture Prickles of Pride”. Fingerprint Life, pages 13-24, 3766, 2016.

[3] Dortort F. "Guide to Succulent plants of the World: A comprehensive Reference to more than 2000 Species." The Timber press, pages 15-23, 28-31, 39-44, 66-67, 101-102, 212, 247, 254-259, 270-271, 282, 296-303. 2011.

\section{WEBLINKS:}

[1] http://www.llifle.com/

[2] https://worldofsucculents.com/ 
International Journal of Research in Advent Technology, Vol.7, No.4, April 2019

E-ISSN: 2321-9637

Available online at www.ijrat.org

[3] https://www.sciencedirect.com/science/art icle/pii/S0960982217302907

[5] https://www.ambius.com/indoor-

plants/the-ultimate-guide-to-succulents/

[4] http://www.newworldencyclopedia.org/ent ry/Ag ave

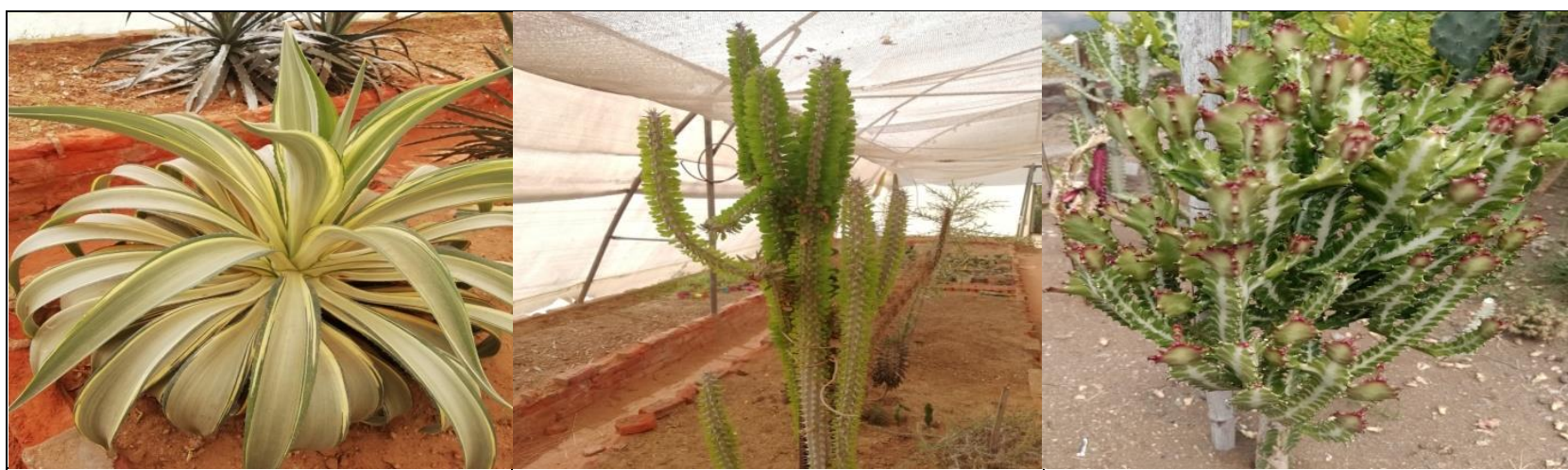

\begin{tabular}{|l|l|l|}
\hline Agave desmintiana var. Joe Hoak & Alludia procera & Euphorbia lactea variegata \\
\hline
\end{tabular}
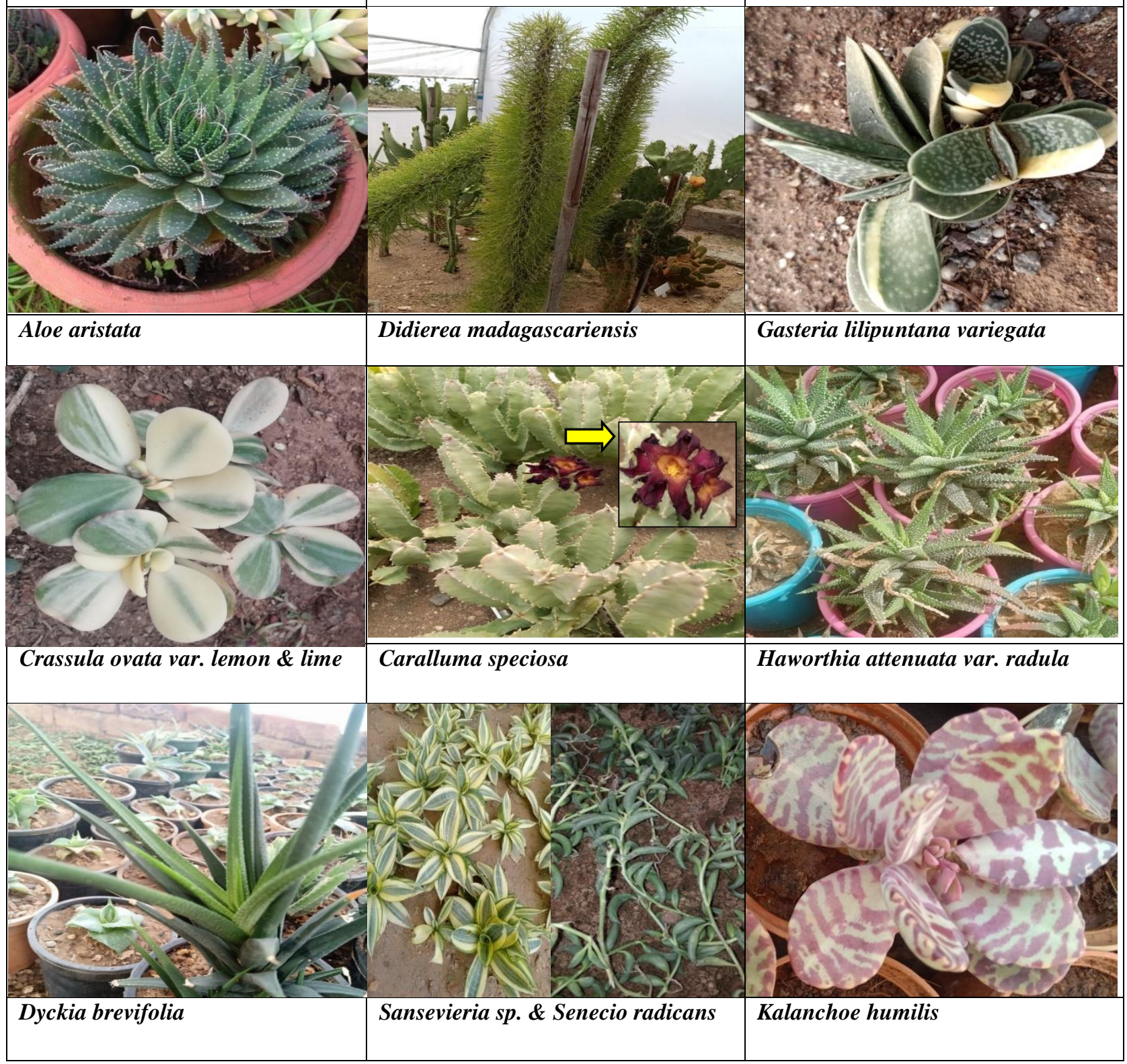

Photoplates: Documentation of 13 Genera of Succulents 